\section{THE EFFECT OF THE PRESENCE OF INFILLING CONCRETE ON FLEXURAL PERFORMANCE OF SPUN PILE - AN EXPERIMENTAL STUDY}

\author{
Candra Irawana*, Rudy Djamaluddin ${ }^{b}$, I Gusti Putu Rakaa, Faimuna, \\ Priyo Suproboa, Gambiroc
}

aDepartment of Civil Engineering, Institut Teknologi Sepuluh Nopember, Surabaya, 60111 , Indonesia

bDepartment of Civil Engineering, Hasanuddin University, Gowa 92172, Indonesia

cPT Wijaya Karya Beton, Tbk., Indonesia
Article history

Received

1 November 2017

Received in revised form

9 October 2019

Accepted

14 October 2019

Published online

25 December 2019

*Corresponding author chandra@ce.its.ac.id

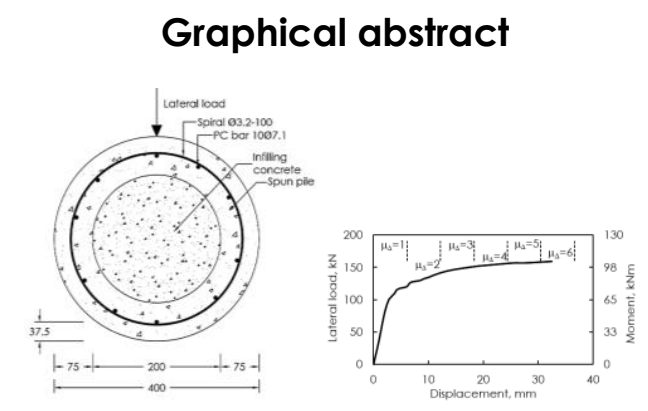

\begin{abstract}
This research investigates the effect of the presence of infilling concrete inside of the middle void of the spun pile on its flexural behavior. The flexural monotonic load without axial load testing was conducted on the full-scale of two spun piles with infilling concrete. The dimensions of the pile were $400 \mathrm{~mm}$ in diameter, $75 \mathrm{~mm}$ in wall thickness, and $6,000 \mathrm{~mm}$ in length. The compressive strength of the concrete of the spun pile and infilling concrete was $58.4 \mathrm{MPa}$ and $26.9 \mathrm{MPa}$ respectively. The observed flexural behaviors were the moment capacity, displacement ductility factor, and failure modes. Comparing with the previous research result about the testing of the spun pile without infilling concrete, the present testing results show that the presence of infilling concrete as the core of the spun pile's section did not have a significant effect on the flexural performances of tested spun pile. Low compressive stress on compression fiber, due to no axial load, caused no concrete crushing occurred and the confinement mechanism of spiral reinforcement did not work. The fracture of the PC bar on extreme tensile fiber become the trigger of the failure of the pile. All piles had a ductility factor around $\mu_{\Delta}=4$ in all cases. According to the seismic design code requirement, the spun piles were appropriate to be applied to a moderate seismic risk area. In application, due to seismic load, the piles should be designed remaining in the elastic state.
\end{abstract}

Keywords: Spun pile, infilling concrete, flexural behavior, displacement ductility factor, monotonic flexural loading

(C) 2020 Penerbit UTM Press. All rights reserved

\subsection{INTRODUCTION}

Some field investigation reports after earthquake hazard showed that severe damage occurred in the pile foundations, not only cast-in-situ but also precast pile. Inertial forces due to building shaking induce overturning moment and base shear force. Both forces cause a high bending moment at the pile to pile cap connection and in the pile shaft beneath soil [1], [2]. The sufficient moment capacity of the pile is required to prevent the pile damaged. Required confinement conducting by transverse reinforcement is also essential to avoid brittle failure. In the 1995 Hyougoken-Nanbu (Kobe) earthquake, more than thirty cases of pile damage were reported by Mizuno et al. [3]. Three types of failure mode are noted, 1) separation between pile caps and pile, 2) pile damage near to pile heads and 3) pile damage below ground level. Post-earthquake investigations discovered some failure patterns occurred on precast prestressed concrete pile foundations, such as due to compressive, shear, combining shear and 
compressive, and flexure. The condition of the pile after excavation was depicted in Figure 1. These types of failure were occurred on precast centrifugally compacted prestressed concrete piles (spun pile).

Starting from the Miyagiken-Oki earthquake in 1978, severe damage of precast prestressed spun concrete piles occurred. The piles with a prestress 4 Mpa were produced until 1984. New seismic design provisions for foundation piles were mandated by the Ministry of Construction in 1984, six years after the earthquake. In this code, piles are required to be designed to resist the loads elastically from the superstructure as large as $20 \%$ the weight of the superstructure. The piles were mainly produced with a prestressing 8 and $10 \mathrm{Mpa}[4]$.

Due to the Kobe Earthquake, large ground settlement and landslides caused damage to piles foundation. The inspection resulted by excavation showed that piles with prestressing 8 and $10 \mathrm{Mpa}$ underwent shear damage on the pile to pile cap connection, and flexural failure occurred on the middle portion of pile shaft [4].

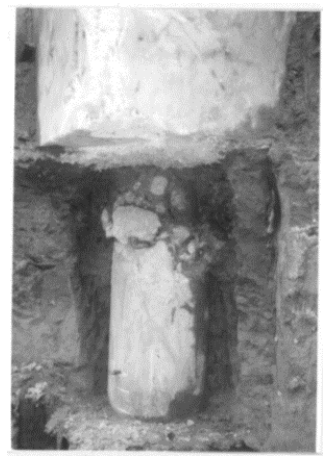

(a) Compressive failure

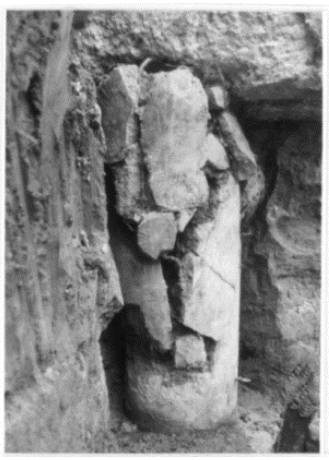

(c) Shear and compressive failure

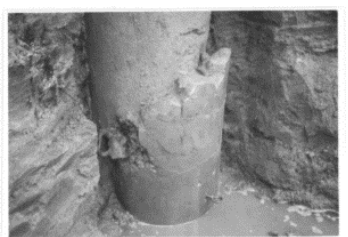

(b) Shear failure

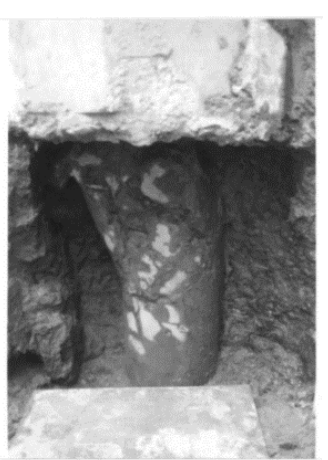

(d) flexure failure
Figure 1 Precast prestressed pile damage due to Hyougoken-Nanbu (Kobe) earthquake 1995 [3]

The current elastic design concept for the pile is not in line with the plastic design concept of superstructure against seismic design load corresponding to a base shear coefficient 0.3 . Therefore, the design provision for spun piles should be revised to order to obtain ductile piles. Presently, spun piles are not provided with transverse reinforcement to resist shear and for the confinement of compressed concrete [4].
This paper primarily investigates the effect of the presence of infilling concrete on the flexural performance of spun pile under monotonic loading without axial load. The infilling concrete application as a concrete core is driven to prevent the inwards crushing of compression concrete fiber that causes the hollow prestressed pile to undergo a brittle failure, as predicted by previous research [5]. The inside face of the wall explosion occurred on a hollow pile [6]. For bending capacity, the greater confinement of the concrete core of the pile section was needed to provide higher ductility [7], [8]. Infilling concrete as the core of the pile's section contributes to the increasing flexural strength of the pile [9]. The flexural strength, ductility factor capacity, and failure mechanism were discussed in this study. The effects of the axial load on the flexural performance of the pile are outside the scope of the present work. These effects will be examined in a future investigation using a cyclic load test.

\subsection{METHODOLOGY}

\subsection{Dimensions of Specimens}

Two spun piles with infilling concrete designated as M-DB-1 and M-DB-2 were prepared for testing under monotonic flexural load. The specimens were the piles that had structural details comparable to those commonly used in Indonesia.

The specimens had a hollow section of the outer $400 \mathrm{~mm}$ diameter with a wall thickness of $75 \mathrm{~mm}$. The distance from the center of the longitudinal PC bar to the outside surface of the concrete was $37.5 \mathrm{~mm}$. The reinforcement of the specimens was a single layer reinforcement consisted of ten PC bars with 7.1 $\mathrm{mm}$ diameter as longitudinal reinforcement and 3.2 $\mathrm{mm}$ diameter of wire as transverse reinforcement with $100 \mathrm{~mm}$ spacing. Figure 2 showed the details of the cross-section and the reinforcement of specimens.

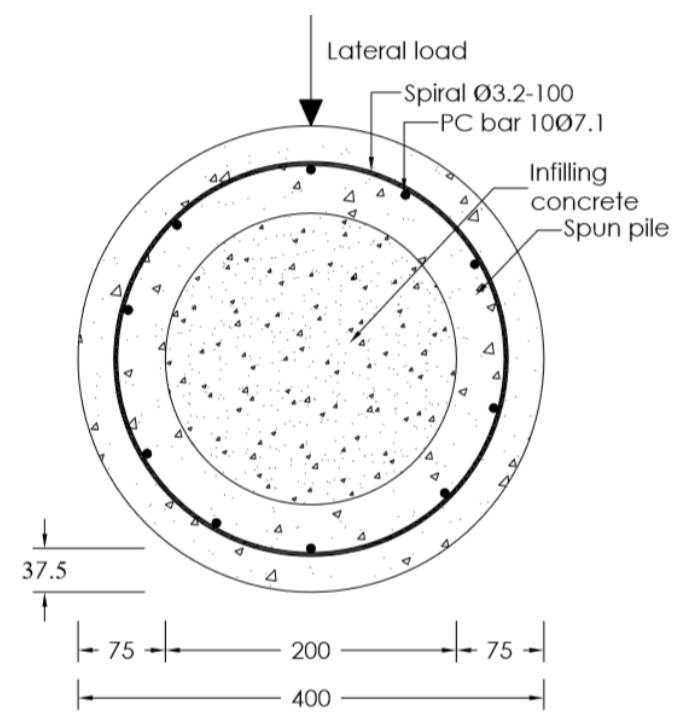

Figure 2 Cross-section and reinforcement of specimens 


\subsection{Properties of Materials}

The essential data of material properties of the specimen were the compressive test of concrete of spun pile and infilling concrete and tensile test of steel, both longitudinal and transverse reinforcement. The average measured compressive concrete strength at 28-day was $58.4 \mathrm{MPa}$. The infilling concrete strength was $26.9 \mathrm{MPa}$. The tensile test result of PC bar $\varnothing 7.1 \mathrm{~mm}$ as longitudinal reinforcement and wire $\varnothing 3.2 \mathrm{~mm}$ as the transverse reinforcement was shown in

Figure 3. Three samples were tested under tensile load, both PC bar and wire. According to the stressstrain result, an idealization of stress-strain was developed.

The summary of the mechanical properties of the PC bar and spiral reinforcement were described in Table 1. The yield and ultimate stress of the PC bar were 1,404 Mpa and 1,469 Mpa, while the yield and ultimate tensile strain of the PC bar were 0.007 and 0.023 . The yield and ultimate stress of wire, transverse reinforcement, was $596 \mathrm{Mpa}$ and $712 \mathrm{Mpa}$, while the yield and ultimate tensile strain of wire were 0.0037 microstrains and 0.0044 microstrains.

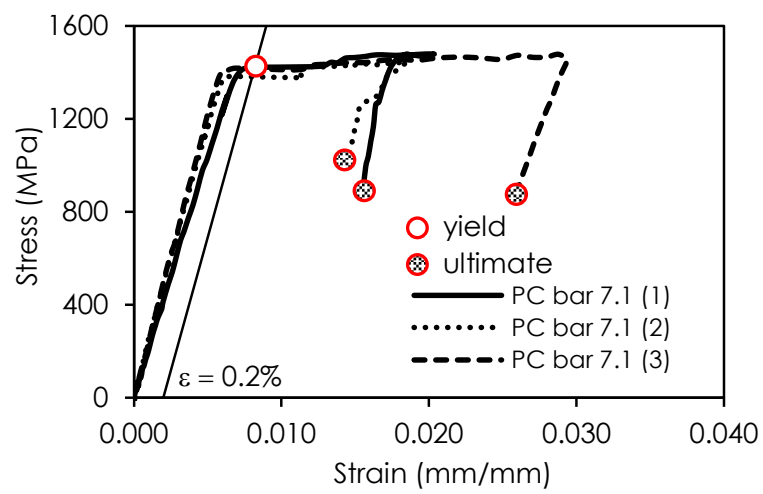

(a) PC bar $\varnothing 7.1$

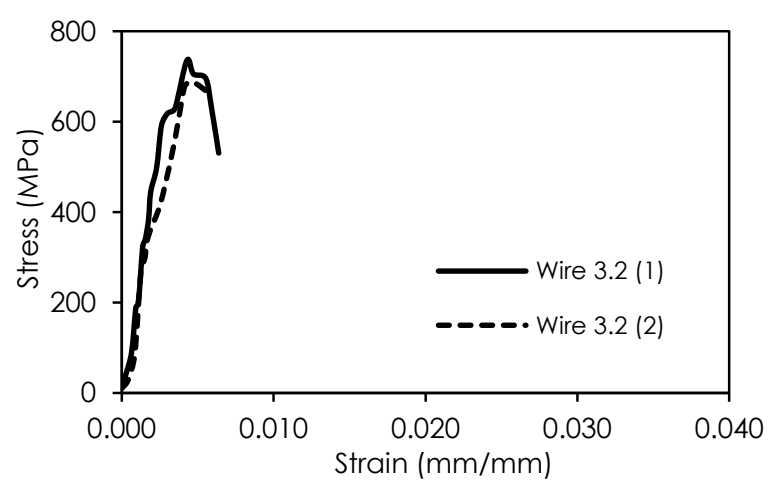

(b) Spiral wire $\varnothing 3.2$

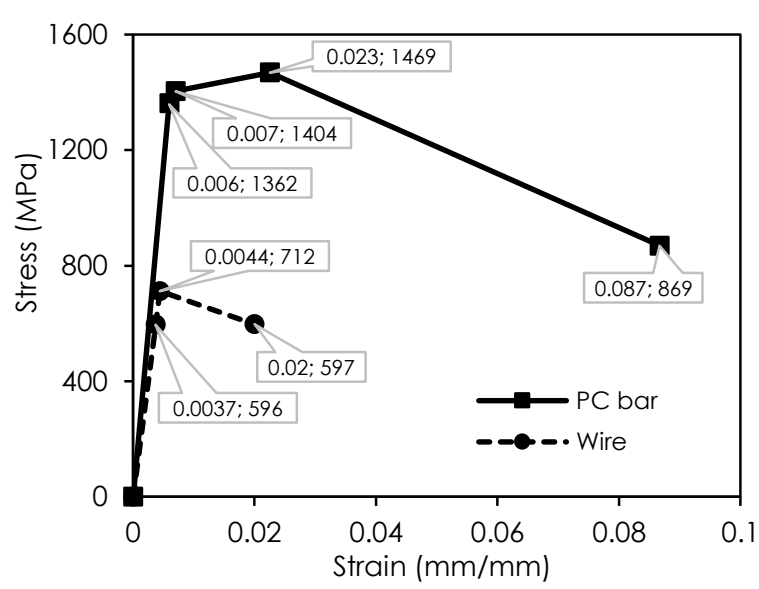

(c) Idealization

Figure 3 Stress-strain of PC bar and spiral wire from the tensile test result

Table 1 Mechanical properties of PC bar and spiral

\begin{tabular}{lcc}
\hline \multicolumn{1}{c}{ Parameter } & PC bar & Spiral Wire \\
\hline Diameter, mm & 7.1 & 3.2 \\
Cross-sectional area, $\mathrm{mm}^{2}$ & 39.6 & 8.0 \\
Modulus of elasticity, MPa & 229,577 & 219,774 \\
Yield stress, MPa & 1,405 & 596 \\
Ultimate stress, MPa & 1,469 & 712 \\
Yield strain & 0.007 & 0.0037 \\
Ultimate strain & 0.023 & 0.0044 \\
Elongation, \% & 8.7 & 2.0 \\
\hline
\end{tabular}

\subsection{Producing of Specimen}

The stages of the production of specimens were shown in Figure 4. The spun piles were produced in the precast concrete factory. The prestressing force was applied to the spun pile by the pretension method. Before casting concrete, strain gauges were mounted on the PC bar and spiral reinforcement to measure the strain during loading.

After the concrete was poured entirely and the mold cover was closed, the prestressing force was applied to the PC bar by prestressing jacks (Figure 4a). The tensile strain of the PC bar due to prestressing is 5,000 micro strains caused the tensile force 1,101 MPa. After casting the spun pile by the spinning method (Figure 4b), at age 6.5 hours, the stress of the PC bar was transferred to concrete by the demolding of concrete (Figure 4c). The initial prestress was 5.4 MPa. The casting of infilling concrete conducted by vertical position (Figure 4d). 


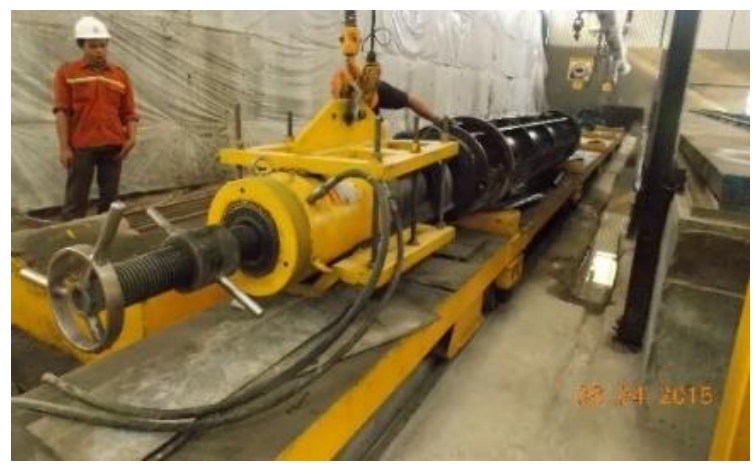

(a) Prestressing process of PC bars

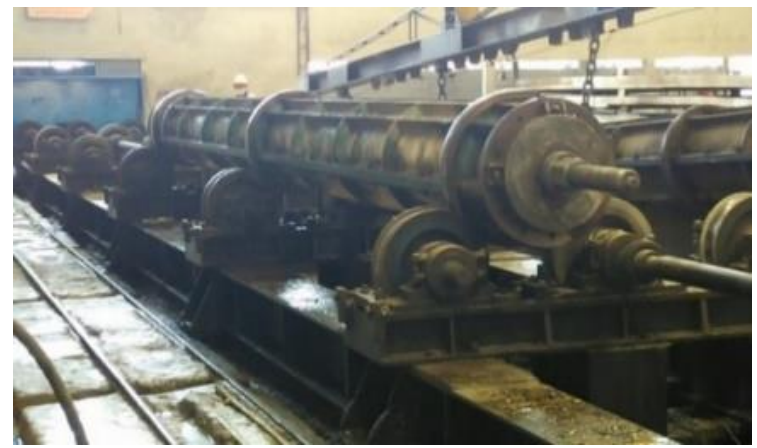

(b) Spinning process

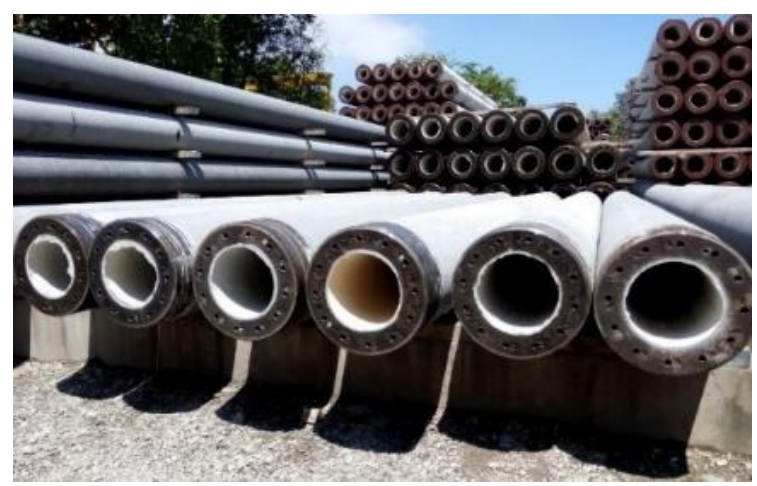

(c) Spun pile after demolding

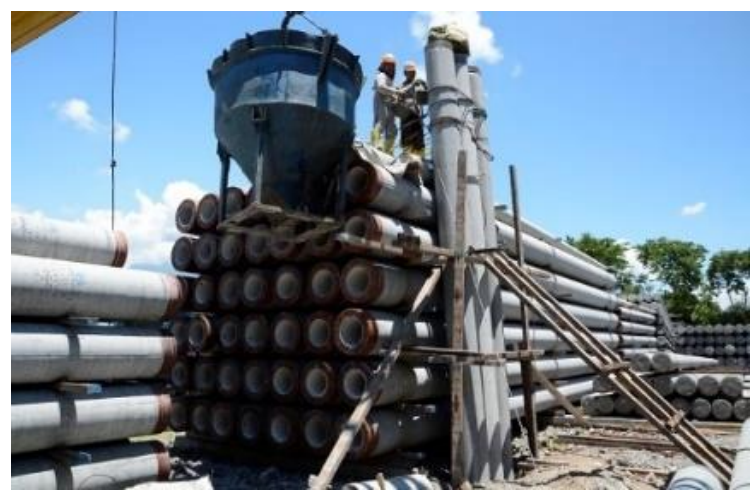

(d) The casting of infilling concrete

Figure 4 The producing process of the specimens

\subsection{Setting up of Testing}

The schematic view of the four points loads testing setup of the specimen, as shown in Figure 5 . According to JIS 53351987 [10], for the length of the pile (L) $6 \mathrm{~m}$, the specimens were supported by pin support developed shear span of specimen $3.6 \mathrm{~m}$ $(3 / 5 \mathrm{~L})$ and cantilever in left and right side of pin

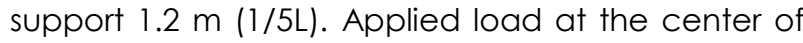
length $(P)$ is distributed as two points load $(P / 2)$ with a distance of each load $1 \mathrm{~m}$.

\subsection{The Instruments of Measurement}

The parameters study in this research were the displacement ductility factor, cracking and ultimate moment capacity, and the strain of the PC bar and concrete. Therefore, the lateral load, displacement, and strain data were recorded to examine the flexural performance of the spun pile.

The lateral load was recorded from the Universal Testing Machine (UTM) load control machine (Figure $5)$. The displacement in the middle span of the specimen was recorded using LVDT, as shown in Figure 6. The strain of PC bar, spiral reinforcement, and concrete recorded by the strain gauge. The position of those strain gauges shown in

Figure 7. The longitudinal strain of concrete was recorded on extreme compressive fiber (top surface), while the PC bar's strain recorded on two layers of reinforcement on the bottom side (PC bar 1 and PC bar 2) and topside (PC bar 3 and PC bar 4). For measuring the confinement concrete, two strain gauges were mounted on spiral reinforcement.

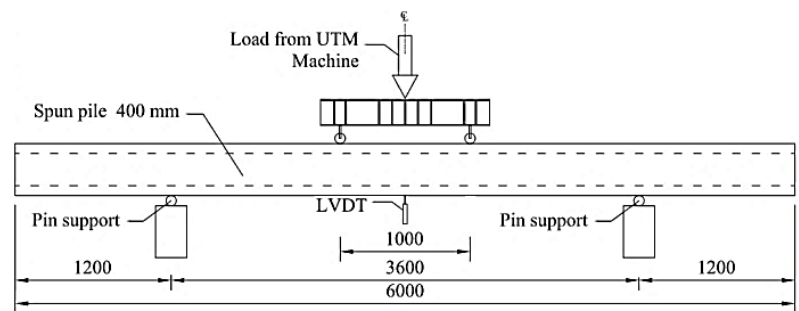

(a)

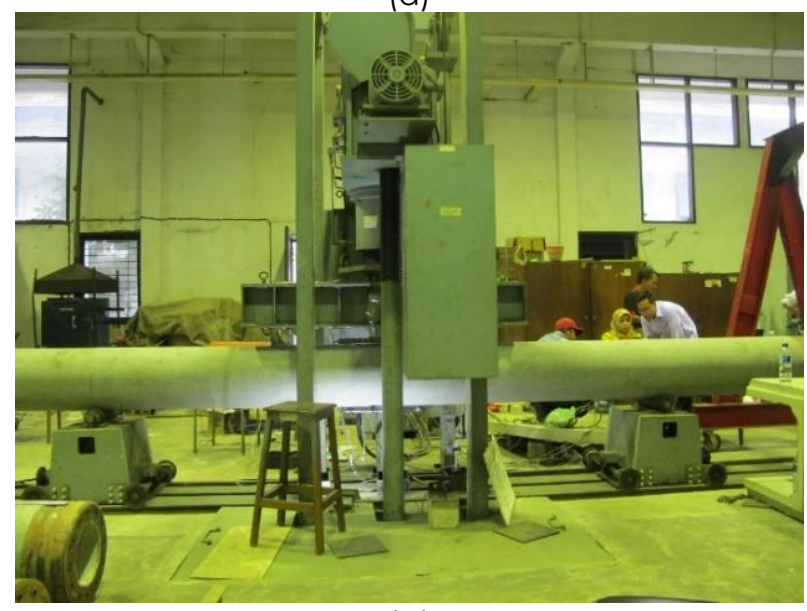

(b)

Figure 5 (a) Test setup schematic view of the specimen and (b) implementation in the laboratory 


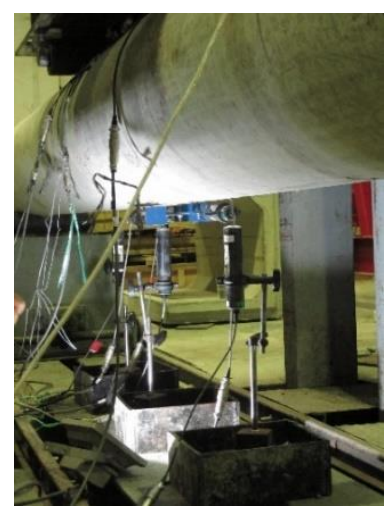

Figure 6 The position of LVDT

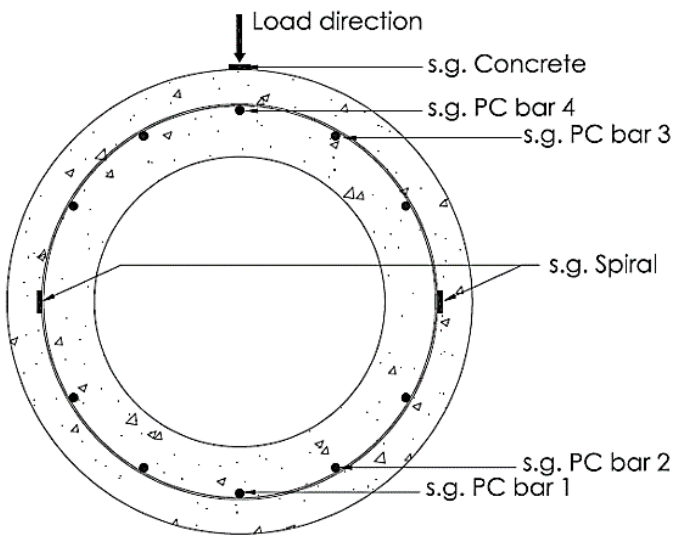

Figure 7 The position of the strain gauge on concrete, PC bars, and spiral reinforcement

\subsection{RESULT AND DISCUSSION}

The flexural performance of all specimens was examined from the bending test results. The measured load (moment)-displacement relationship and strain behavior of concrete, PC bar and, spiral reinforcement were analyzed. Ultimate displacement, ductility factor, cracking, yield, and ultimate moments were analyzed from loaddisplacement data while the failure mode was analyzed from strain's data of PC bar and concrete. The displacement ductility factor analysis was conducted corresponding to Japan seismic design provision and NEHRP 2000.

\subsection{Load-Displacement}

The curves of the lateral load versus the displacement at the middle span of the spun pile with concrete infilling were shown in

Figure 8. Both curves were denoted the summary of the moment capacity of the spun pile with infilling concrete as shown in Table 2 . The average cracking and ultimate moment was $62.2 \mathrm{kNm}$ and $100.4 \mathrm{kNm}$, respectively. The previous research, Irawan et al. (2016) conducted testing on the hollow spun pile resulted from load and displacement curve as shown in Figure 9 [12]. As shown at Table 3, the hollow spun pile had the average of the cracking and the ultimate moment $59.5 \mathrm{kNm}$ was $103.3 \mathrm{kNm}$ respectively. The hollow spun pile had the average of the cracking and the ultimate moment $59.5 \mathrm{kNm}$ was $103.3 \mathrm{kNm}$, respectively. The presence of concrete slightly increases the cracking moment of the spun pile. The ultimate strength was not to be affected due to the presence of infilling concrete.

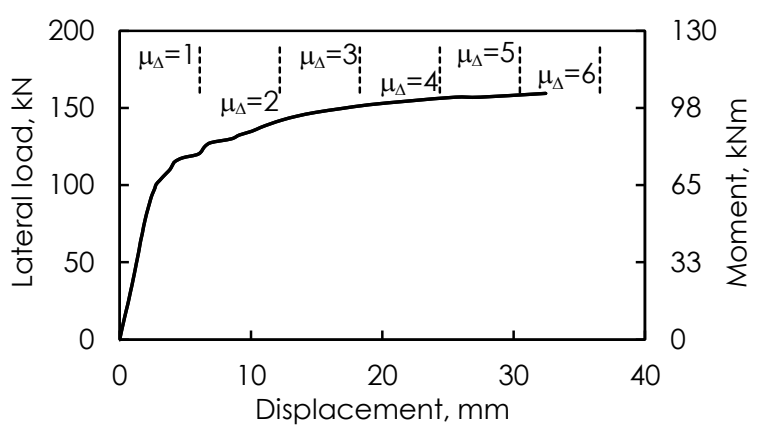

(a) M-DB-1

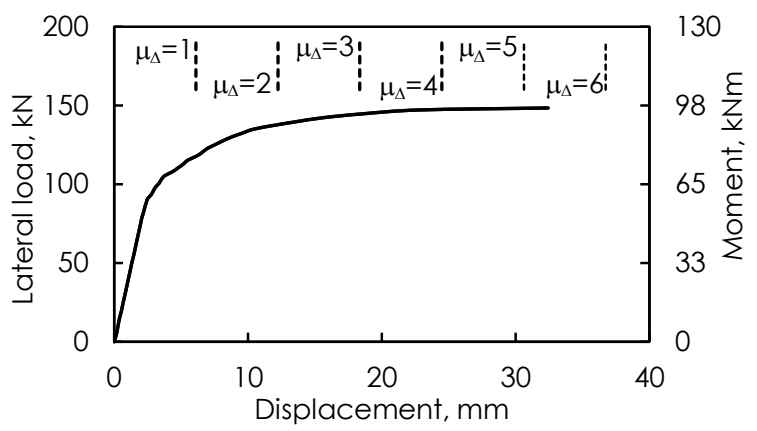

(b) M-DB-2

Figure 8 The curve of lateral load, moment and displacement of the spun pile with infilling concrete

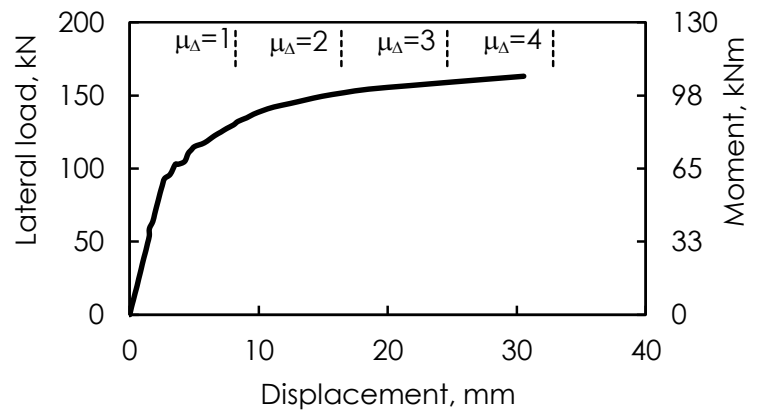

(a) $M-T B-1$

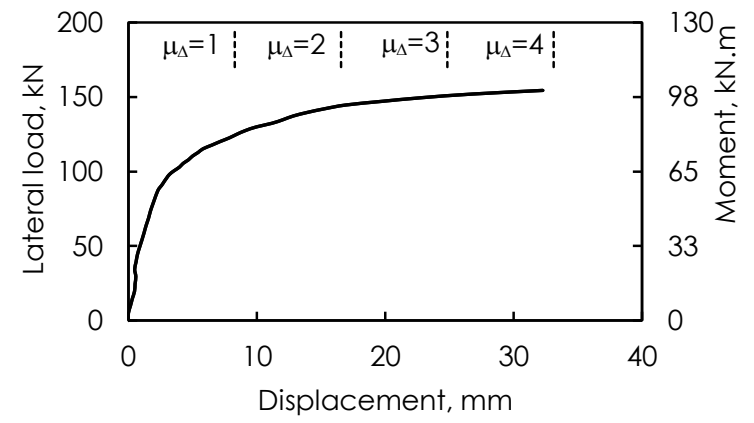

(b) M-TB-2 


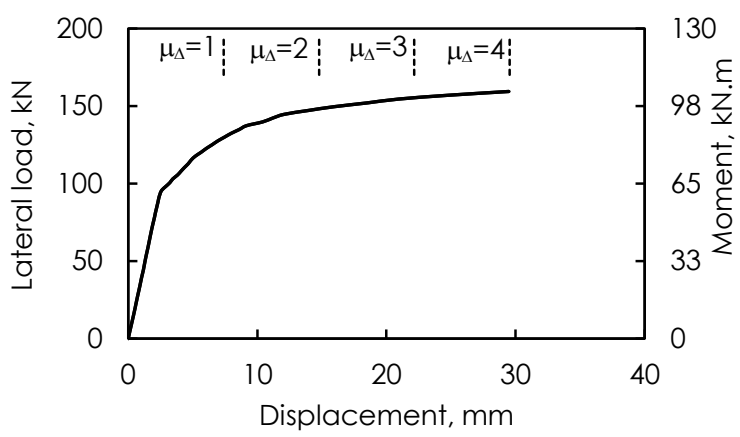

(c) M-TB-3

Figure 9 Lateral load, moment and displacement curve of hollow spun pile [12]

Table 2 The summarize of the crack and ultimate moments of the spun pile with infilling concrete

\begin{tabular}{ccc}
\hline \multirow{2}{*}{ Specimen } & \multicolumn{2}{c}{ Moment, kNm } \\
\cline { 2 - 3 } & Crack & Ultimate \\
\hline M-DB-1 & 65.4 & 104,3 \\
M-DB-2 & 59.0 & 96,4 \\
\hline Average & $\mathbf{6 2 . 2}$ & $\mathbf{1 0 0 . 4}$ \\
\hline
\end{tabular}

Table 3 The summarize of crack and ultimate moments of the hollow spun pile [12]

\begin{tabular}{ccc}
\hline \multirow{2}{*}{ Specimen } & \multicolumn{2}{c}{ Moment, kNm } \\
\cline { 2 - 3 } & Crack & Ultimate \\
\hline M-TB-1 & 60.5 & 106.1 \\
M-TB-2 & 57.3 & 100.3 \\
M-TB-3 & 58.9 & 103.5 \\
\hline Average & $\mathbf{5 8 . 9}$ & $\mathbf{1 0 3 . 3}$ \\
\hline
\end{tabular}

Figure 8 also depicted the yield and ultimate displacement of the pile. The yield state occurred when the PC bar stress attained yield condition. Whereas the ultimate state was described as the condition when spun pile failure. As shown in Table 4 the yield and ultimate displacement were $6.1 \mathrm{~mm}$ and $31.6 \mathrm{~mm}$, respectively. The average displacement ductility factor of the spun pile with infilling concrete was $\mu_{\Delta}=5.2$. It was higher $38 \%$ than hollow spun pile $\mu_{\Delta}=3.7$ as shown in Table 5 . The higher moment of inertia caused a pile with infilling concrete yielding in lower displacement compared with the hollow pile. Slightly higher ultimate displacement obtained due to the presence of infilling concrete.

Table 4 Summarize of displacement and ductility factor of the spun pile with infilling concrete

\begin{tabular}{cccc}
\hline \multirow{2}{*}{ Specimen } & \multicolumn{2}{c}{$\begin{array}{c}\text { Displacement, } \\
\text { mm }\end{array}$} & $\begin{array}{c}\text { Displacement ductility } \\
\text { factor }\end{array}$ \\
\cline { 2 - 3 } & Yield & Ultimate & \\
\hline M-DB-1 & 6.1 & 30.5 & 5.0 \\
M-DB-2 & 6.1 & 32.7 & 5.3 \\
\hline Average & $\mathbf{6 . 1}$ & $\mathbf{3 1 . 6}$ & $\mathbf{5 . 2}$ \\
\hline
\end{tabular}

Table 5 Summarize of displacement and ductility factor of hollow spun pile [12]

\begin{tabular}{cccc}
\hline Specimen & \multicolumn{2}{c}{$\begin{array}{c}\text { Displacement, } \\
\mathbf{m m}\end{array}$} & $\begin{array}{c}\text { Displacement ductility } \\
\text { factor }\end{array}$ \\
\cline { 2 - 3 } & Yield & Ultimate & 3.5 \\
M-TB-1 & 8.7 & 30.6 & 3.5 \\
M-TB-2 & 8.9 & 33.2 & 3.7 \\
M-TB-3 & 7.4 & 29.5 & 4.0 \\
\hline Average & $\mathbf{8 . 3}$ & $\mathbf{3 1 . 1}$ & $\mathbf{3 . 7}$ \\
\hline
\end{tabular}

\subsection{Failure Mechanism}

\subsubsection{Crack Pattern}

Due to the monotonic flexural load without axial load failure pattern of the spun pile was dominated by cracking and no crushing of concrete on compressive fiber. Figure 10 shown this failure condition. The severe crack was visible on the spun pile shaft, almost all depth of pile's diameter. The crack was distributed through the length of the distance between the two points load. While peak load achieved, the crushing failure of concrete at compressive fiber did not occur, and the sound of the PC bar's breaking was heard. Therefore, the failure of the spun pile was initiated by the fracture PC bar.

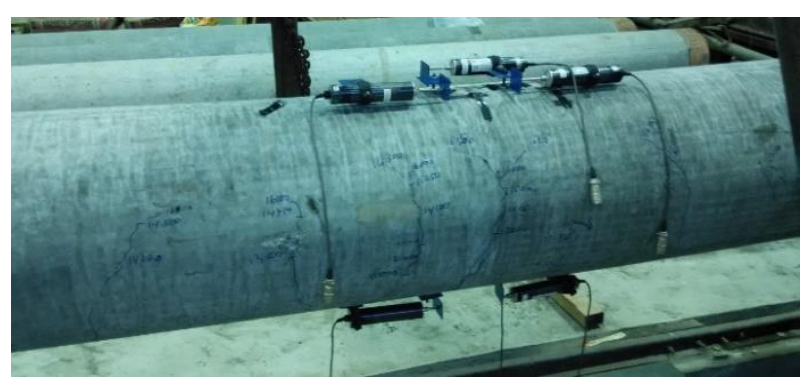

Figure 10 The failure condition of specimen M-DB-1 after peak load achieved

The complete crack's pattern of all specimens was depicted in Figure 11. Visually, failure's pattern of all tested spun pile was similar both hollows spun pile (M-TB) and spun pile with infilling concrete (M-DB). The extensive cracking occurred exceeded the level of PC bar 3 (343 mm from the bottom side of the pile, $86 \%$ of depth). The crushing of concrete did not occur in compressive fiber. A similar damage pattern was shown in previous research [19], flexural testing on the spun pile generates cracks which distributed in the full range along with the pile. 

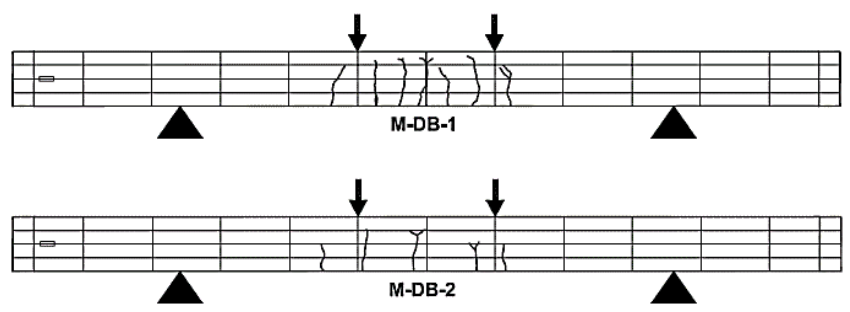

Figure 11 The crack patterns of the tested spun pile at the maximum load spun pile with concrete infilling
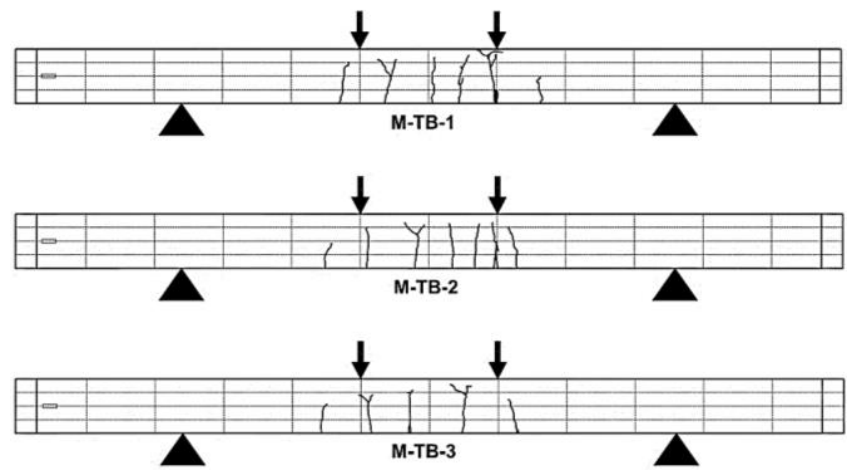

Figure 12 The crack patterns of the tested spun pile at the maximum load spun pile without concrete infilling [12]

\subsubsection{The Strain of PC Bar and Concrete}

The failure mechanism of the spun pile due to the flexural test was evaluated according to the recorded strain of PC bar, concrete, and spiral reinforcement. The position of strain gauge was shown in Figure 7. The strain data of the PC bar was recorded both on compressive and tensile fiber. Meanwhile, the longitudinal strain of concrete data just recorded on compressive fiber. The concrete confinement by spiral transverse reinforcement of the pile was analyzed using the strain mounted on spiral reinforcement.

The recorded strain's data of PC bars and concrete of spun pile with concrete infilling M-DB during testing was shown in Figure 12. Comparing with the previous testing results of the spun pile without infilling concrete Figure 12, Both specimens, M-DB and M-TB had a similar development of strain's pattern either tensile strain of PC bar or compressive strain of concrete. At the ultimate state, the maximum strain of concrete on extreme compressive fiber was 0.0021 and 0.0023 for specimen M-DB- 1 and M-DB-2, respectively. These strains were less than the crushing strain at the extreme concrete compressive fiber $\varepsilon_{c u} 0.003$ [11], therefore, the concrete on extreme compressive fiber was not crushing.

The recorded strain of the PC bar depicted before peak load was attained the tensile strain of PC bars was increasing plastically. The recorded maximum strain was around 0.012 . The strain rapidly increased until the maximum moment achieved. Afterward, the strain of the PC bar suddenly decreased. It denoted that the PC bar was broken. The ultimate tensile strain of the PC bar could not record by the strain gauge. From tensile properties data, the predicted tensile strain of the PC bar was $\varepsilon_{p u}=0.023-0.005=0.018$, whereas 0.023 and 0.005 is the ultimate strain and initial prestressing strain of PC bar, respectively.

By recorded strain data of the PC bar explained above, the failure occurred due to the breaking of the tension PC bar. This failure mechanism of the PC bar was similar to previous research [19]. The crushing of the compression concrete of the pile section did not occur. The strain of PC bar and concrete at the ultimate condition was shown in Figure 14. The position of the neutral axis was almost depth of pile $\left(\mathrm{yb}_{\mathrm{b}}=362 \mathrm{~mm}\right)$. This data was conformable with crack distribution (Figure 11).

Distinct failure mechanisms of hollow section piles were obtained from this test, no crushing occurred. Generally, the ultimate states of a hollow column or pile were initiated by concrete crushing on compressive fiber [15], [17]. For a large diameter of the circular hollow column, an explosion occurred on the inside surface of the concrete wall on compressive fiber [18].

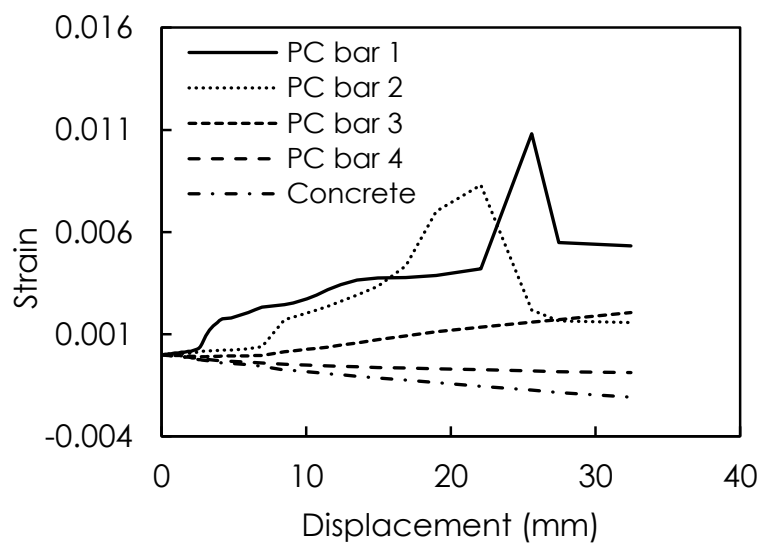

(a) $M-D B-1$

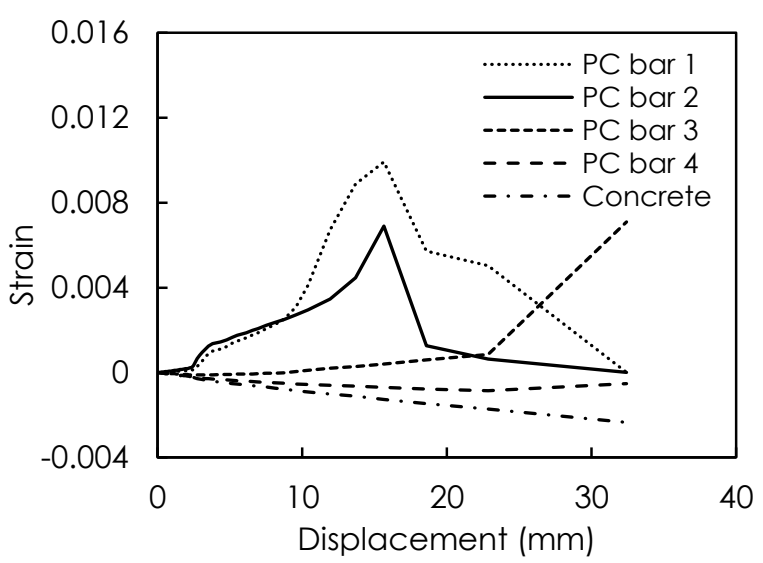

(b) M-DB-2

Figure 13 Strain of $\mathrm{PC}$ bar and concrete of spun pile with concrete infilling $M-D B$ 


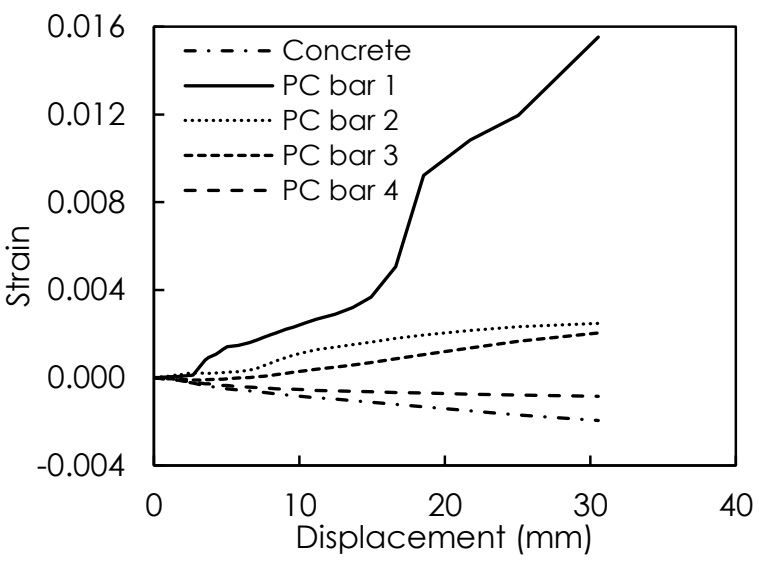

(a) M-TB-1

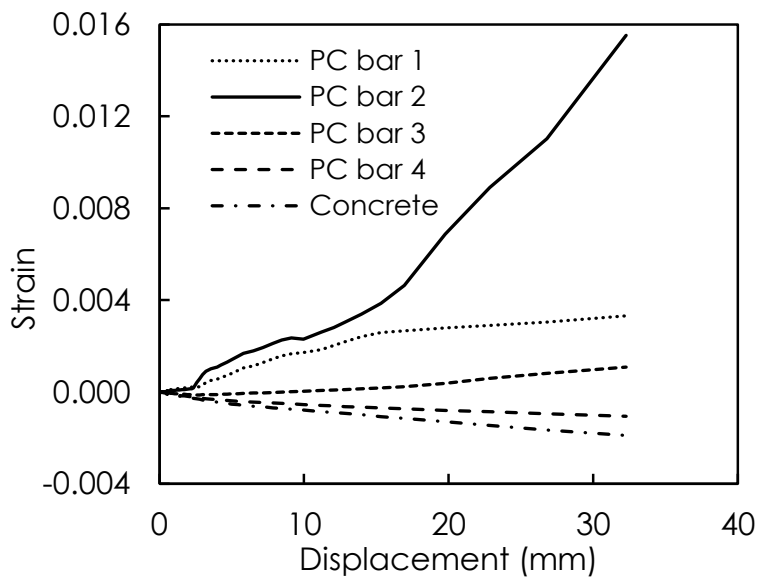

(b) M-TB-2

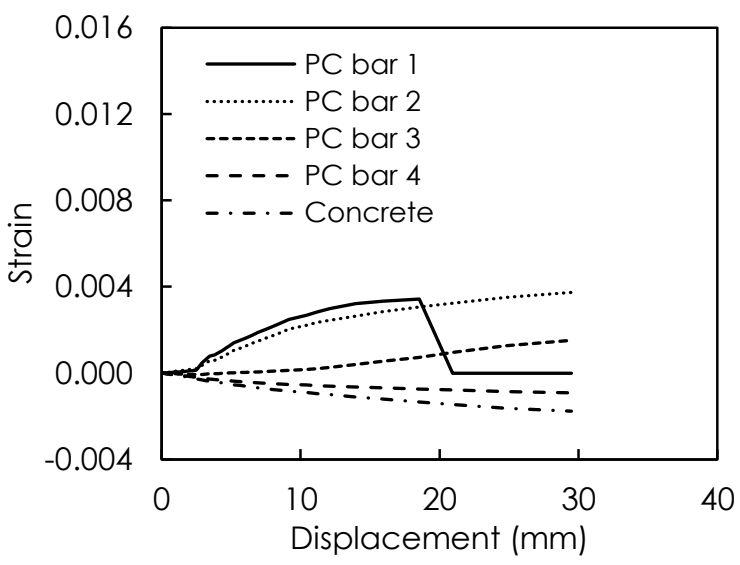

(c) $\mathrm{M}-\mathrm{TB}-3$

Figure 14 Strain of PC bar and concrete of spun pile without concrete infilling M-TB [12]

\subsubsection{The Strain of Spiral Transverse Reinforcement}

The recorded strain of spiral reinforcement was shown in Figure 15 and Figure 16. Small tensile strains of spiral transverse reinforcements were recorded. It indicated that the confinement of concrete did not work significantly. The tensile strain of spiral reinforcement in the flexural region was less than 200 microstrain (0.0002), did not reach the yield strain 0.0037 before failure. The spiral confinement phenomena did not occur. These facts suggest that the limited lateral pressure is induced in the concrete wall, and thus, the inside face concrete of the spun pile is subjected to poor confinement [17], [18], [6].

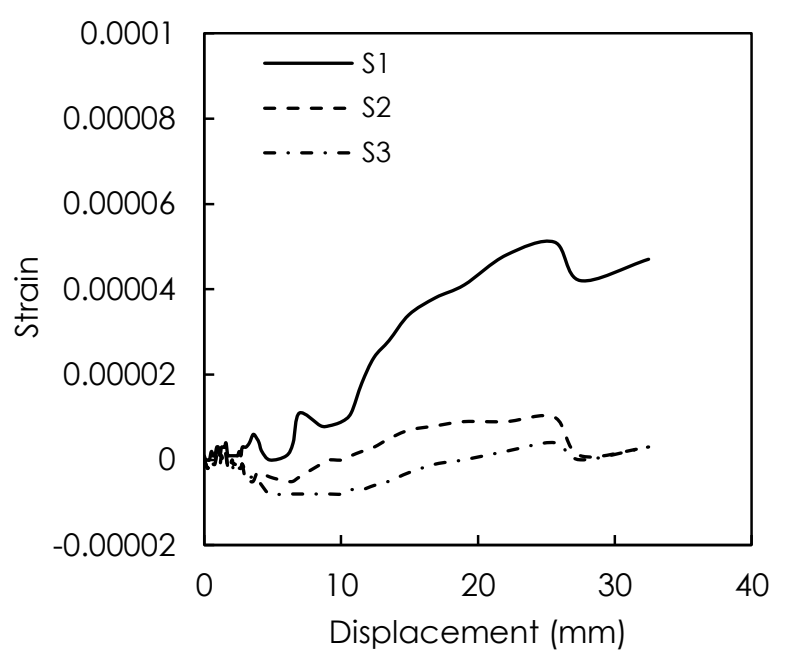

(a) M-DB-1

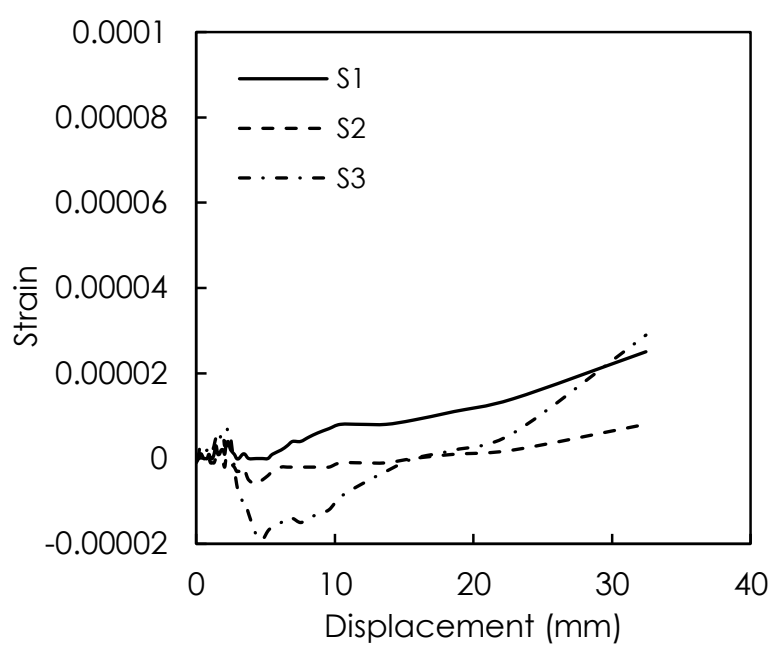

(b) M-DB-2

Figure 15 The strain of spiral reinforcement spun pile with concrete infill

This type of failure was unlike previous research. Budek et al. 2000 and Akiyama et al. emphasized that the failure of a hollow prestressed pile initiated by crushing inside the face of the pile's shell [1], [9]. Therefore, in addition to confinement of compression concrete, the ultimate capacity of tensile reinforcement also determined the flexural performance of the spun pile. An adequate amount and sufficient ultimate tensile strain capacity of longitudinal reinforcement should be provided to obtain high strength and ductility factor of the spun pile.

The confinement of concrete behavior of the hollow concrete column is different from that established for solid sections [16]. The presence of infilling concrete contributed a relatively minor role in the confining strain of spiral transverse reinforcement. If the compression zone of a concrete member has adequate confinement, the ductility of the concrete 
may be greatly improved, and a more ductile performance of the member at the ultimate load will result [20].

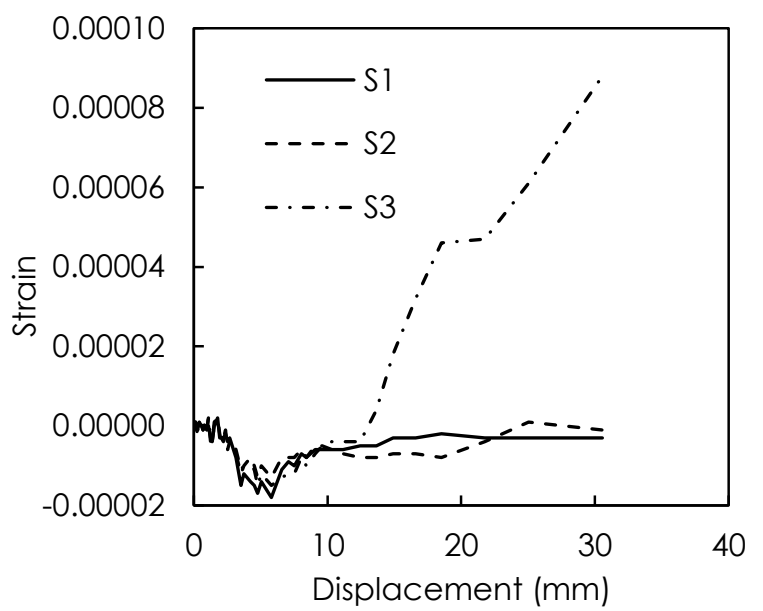

(a) M-TB-1

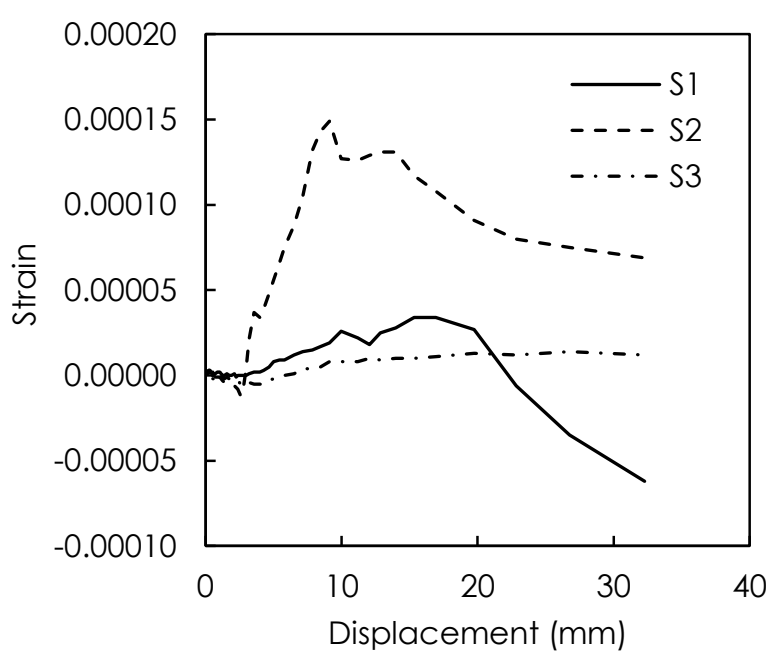

(b) M-TB-2

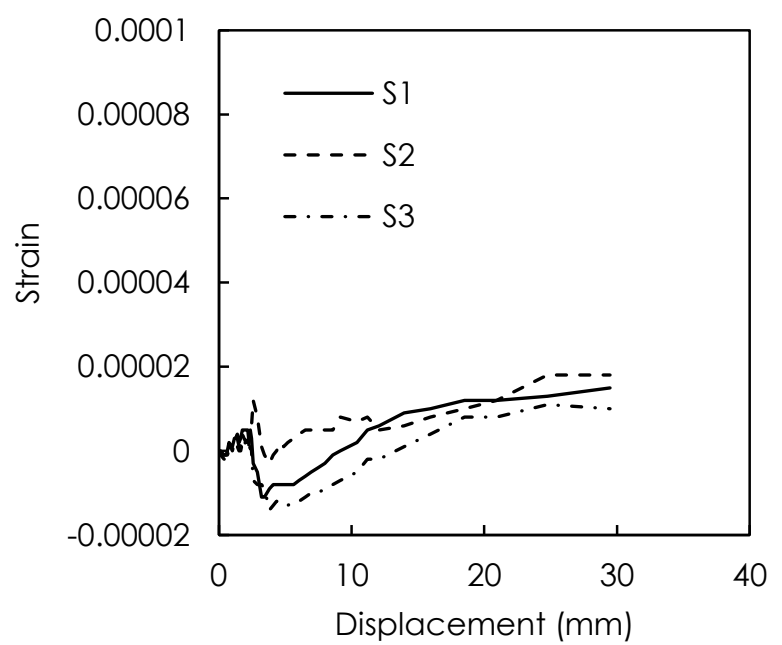

(c) $M-T B-3$

Figure 16 The strain of spiral reinforcement spun pile without concrete infill

\subsection{Displacement Ductility Factor Analysis}

According to NEHRP 2000 and Japan seismic design provision for the foundation, there are three states of pile foundation corresponding to the value of displacement ductility factors provided by pile members. The limits values of displacement ductility factors are obtained on the testing results. The summary of the requirements was depicted in Table 6 [13], [14].

Table 6 The state of pile foundation corresponding to the value of displacement ductility [13], [14]

\begin{tabular}{|c|c|c|c|}
\hline \multirow{2}{*}{$\begin{array}{l}\text { State of pile } \\
\text { foundation }\end{array}$} & \multirow{2}{*}{$\begin{array}{c}\text { Seismic } \\
\text { design } \\
\text { category }\end{array}$} & \multicolumn{2}{|c|}{ Limits value of $\mu_{\Delta}$} \\
\hline & & $\begin{array}{l}\text { Japan } \\
\text { code }\end{array}$ & NEHRP 2000 \\
\hline $\begin{array}{l}\text { Pile foundation } \\
\text { does not yield. }\end{array}$ & $A$ and $B$ & 1 & $\begin{array}{c}\text { No } \\
\text { requirement }\end{array}$ \\
\hline $\begin{array}{l}\text { Although pile } \\
\text { foundation yield, } \\
\text { they maintain a } \\
\text { sufficient bearing } \\
\text { capacity. }\end{array}$ & C & 5 & 4 \\
\hline $\begin{array}{l}\text { Although the pile } \\
\text { foundation } \\
\text { reaches the limit } \\
\text { state, } \\
\text { superstructures } \\
\text { not collapse. }\end{array}$ & $\begin{array}{c}D, E, \text { dan } \\
F\end{array}$ & 8 & 8 \\
\hline
\end{tabular}

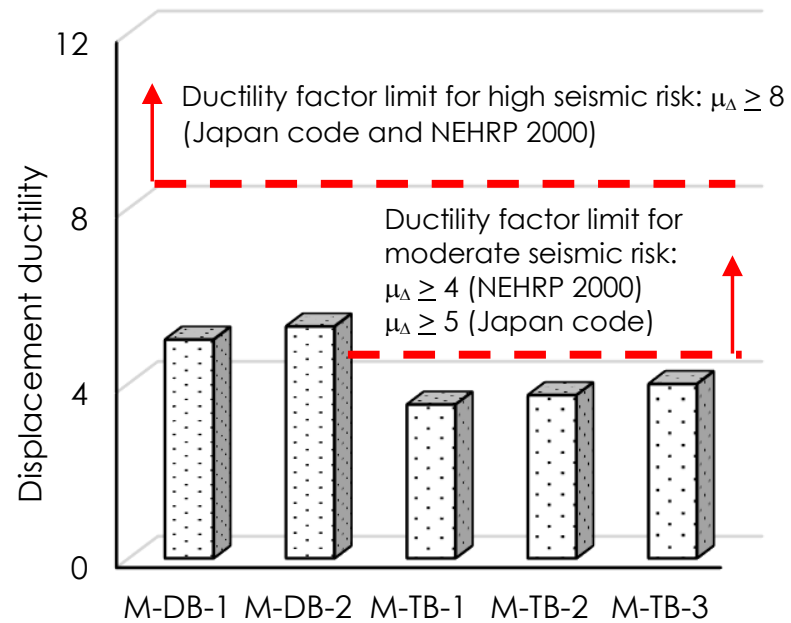

Figure 17 The displacement ductility factor of tested piles and seismic codes requirement

The analysis of the seismic performance of the spun pile was conducted by comparing the displacement ductility factor of tested piles with code requirements. According to Table 4 and Table 5 , the displacement ductility factor of the spun pile with infilling concrete was more than 4 , as shown in Figure 17. These ductility factors were included moderate seismic risk use range. Therefore, the tested pile was appropriate to be used in a moderate seismic area. In application, due to seismic load, the piles were required to remain in the elastic 
state, do not yield. Further research was required to obtain a ductile spun pile with high displacement ductility factor capacity to be used on moderate or high seismic risk areas.

\subsection{CONCLUSION}

Experimental investigations on the influence of infilled concrete in pure flexural behavior of large-scale spun piles were undertaken. From the experiment presented, it can be concluded that infilled concrete does increase the cracking moment resistance, while the yield and ultimate moment resistance seem unaffected. Comparing to the results of the ordinary hollow spun pile, it is also found that the ductility of the spun pile with infilled concrete is increased by circa $38 \%$. Accordingly, the failure of the spun pile observed during the experiment was generally triggered by the fracture of the PC bar(s) prior to concrete crushing at extreme compression fiber.

Apart from the experimental results, analysis referring to design code NEHRP 2000 was carried out to examine the appropriate use of this member in the earthquake region. It is found that the proposed spun pile is suitable in a moderate seismic risk area. In application, due to seismic load the piles were required to remain in the elastic state, do not yield. Further research was required to obtain a ductile spun pile with high displacement ductility factor capacity to be used on high seismic risk areas.

\section{Acknowledgment}

The authors would like to acknowledge: The Ministry of Research, Technology and the Higher Education Republic of Indonesia, PT Wijaya Karya Beton, Tbk. for funding through research collaboration of ITS Surabaya, UNHAS Makassar and PT Wijaya Karya Beton, Tbk.

\section{References}

[1] Budek, A. M., Priestley, M. J. N., and Benzoni, G. 2000 Inelastic Seismic Response of Bridge Drilled-Shaft RC Pile/Columns. Journal of Structural Engineering. 126(4): 510-517. DOI: 10.1061/(ASCE)0733-9445(2000)126:4(510).

[2] Budek, A., and Benzoni, G. 2008. Rational Seismic Design of Precast, Prestressed Concrete Piles. PCl Journal. 55(5): 40-53. DOI: 10.15554/pcij.09012008.40.53.

[3] Mizuno, H., liba, M., and Hirade, T. 1996. Pile Damage during 1995 Hyogoken-Nanbu Earthquake in Japan. Proceeding of Eleventh World Conference on Earthquake Engineering Paper No. 977.
[4] Muguruma, H., Nishiyama, M., and Watanabe, F. JulyAugust, 1995. Lessons Learned from the Kobe Earthquake: A Japanese Perspective. PCl Journal. 40(4): 28-42. DOI: 10.15554/pcii.0701 1995.28.42.

[5] Banerjee, S., Stanton, J. F., and Hawkins, N. M. 1987. Seismic Performance of Precast Prestressed Concrete Piles. Journal of Structural Engineering. 113(2): 381-396.

[6] Hoshikuma, J. and Priestley, M. J. N. 2000. Flexural Behavior of Circular Hollow Columns with a Single Layer of Reinforcement under Seismic Loading. Final Research Report for Caltrans under Contract No. 59A0051.

[7] Nigels, M. C. 2005. Design of Prestressed Concrete Piles for Seismic Load Adds a New Dimension. Piledriver. Q4: 32-36.

[8] Mander, J. b., Priestly, M. J. N., Park, R. 1988. Observed Stress-Strain Behavior of Confined Concrete. Journal of Structural Engineering. 114(8): 1827-1849.

DOI: 10.1061/(ASCE)0733-9445(1988)114:8(1827).

[9] Akiyama, M., Abe, S., Aoki, N. and Suzuki, M. 2012. Flexural Test of Precast High-strength Reinforced Concrete Pile Prestressed with Unbonded Bars Arranged at the Center of the Cross-section. Engineering Structures Journal. 34. 259-270. DOI:10.1016/j.engstruct.2011.09.007.

[10] Japanese Standards Association. 1987. Japan Industrial Standard Pretensioned Concrete Spun pile JIS A-5335, Japanese Standards Association, Japan.

[11] ACl Committee 318M. 2014. Building Code Requirements for Structural Concrete and Commentary, American Concrete Institute, Farmington Hills.

[12] Irawan, C., Djamaluddin, R., Raka, I. G. P., and Suprobo, P. 2016, October. The Experimental Investigation of Failure Mechanism of Spun Pile due to Monotonic Loading using NEHRP 2000. 4th International Conference on Protective Structures (ICPS4).

[13] Hawkins, N. M. and Ghosh, S. K. 2000, SeptemberOctober. Proposed Revisions to 1997 NEHRP Recommended Provisions for Seismic Regulations for Precast Concrete Structure Part 2 - Seismic-ForceResisting Systems. PCI Journal. 34-44.

[14] Takase, N., Ikegame, M., Tanamura, S., Nishimura, A. and Kondou, M. 1999. Seismic Design of Pile Foundation. QR of RTRI. 40(3): 152-157. http://doi.org/10.2219/rtriqr.40.152.

[15] Budek, A. M., and Priestly, M. J. N. 2005. Experimental Analysis of Flexural Hinging in Hollow Marine Prestressed Pile Shaft. Coastal Engineering Journal. 47(1): 1-20. https://doi.org/10.1142/S0578563405001161.

[16] Liang, X., Beck, R., and Sritharan R. 2015. Understanding the Confined Concrete Behavior on the Response of Hollow Bridge Column. Caltrans Project, lowa State University of Science and Technology, Department of Civil, Construction and Environmental Engineering. Report No. CA14-2264.

[17] Zahn, F., Park, R., and Priestly, M. J. N. 1990. Flexural Strength and Ductility of Hollow Reinforced Concrete Columns without Confinement on Inside Face. $\mathrm{ACl}$ Structural Journal. 87(2): 156-166.

[18] Hoshikuma, J., and Priestley, M. J. N. 2000. Flexural Behavior of Circular Hollow Columns with a Single Layer of Reinforcement under Seismic Loading. Caltrans Project, Department of the Structural Engineering University of California, San Diego La Jolla, California 92093-0085. Report No SSRP 2000/13.

[19] Tuladhar, R., Mutsuyoshi, H., Maki, T., and Daigo, K. 2005. Lateral Loading Tests of Full Scaled Concrete Piles Embedded into the Ground. Bulletin of Engineering Faculty of Saitama University. 38: 74-80.

[20] Park, R. and Paulay T. 1975. Reinforced Concrete Structure. John Wiley \& Sons, Inc. 